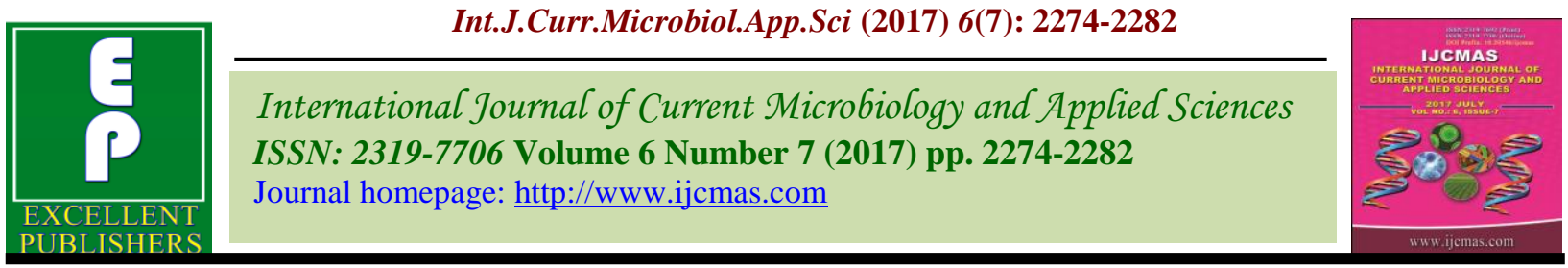

Original Research Article

https://doi.org/10.20546/ijcmas.2017.607.267

\title{
Effect of Irrigation Management and Plant Population on the Performance of Summer Babycorn (Zea mays L.)
}

\author{
R.K. Meena*, R.C. Tiwari and V.D. Meena, J.L. Charpota and A.K. Meena \\ Department of Agronomy, Rajasthan College of Agriculture, MPUAT, Udaipur-313 001, India \\ *Corresponding author
}

\author{
A B S T R A C T
}

\begin{tabular}{|l|}
\hline Key w or d s \\
Baby corn, \\
$\begin{array}{l}\text { Irrigation } \\
\text { schedule, Planting } \\
\text { density, Yield. }\end{array}$ \\
\hline Article Info \\
\hline $\begin{array}{l}\text { Accepted: } \\
\text { 21 June } 2017 \\
\text { Available Online: } \\
\text { 10 July } 2017\end{array}$ \\
\hline
\end{tabular}

A field experiment was conducted during summer season of 2015 to find out the suitable irrigation level and plant population forgetting good performance by summer baby corn, at the instructional Farm of the Rajasthan College of agriculture, MPUAT, Udaipur, Rajasthan. The treatments consisted of three irrigation level viz. 0.8IW/CPE (I1), 1.0IW/CPE (I2) and 1.2IW/CPE (I3) with six plant population levels viz. 66,666 plants per ha $\left(\mathrm{P}_{1}\right), 83,333$ plants per ha $\left(\mathrm{P}_{2}\right), 88,888$ plants per ha $\left(\mathrm{P}_{3}\right), 1,11,111$ plants per ha $\left(\mathrm{P}_{4}\right)$, $1,33,333$ plants per ha $\left(\mathrm{P}_{5}\right)$ and $1,66,666$ plants per ha $\left(\mathrm{P}_{6}\right)$. The results showed that the baby corn irrigated at $1.0 \mathrm{IW} / \mathrm{CPE}$ (I2) produced taller plants with higher baby corn length and width, dry matter production, number of baby corn per plant, weight of baby corn which results in higher green fodder and baby corn yield. Irrigation at 1.0IW/CPE (I2), produced higher baby corn yield with and without husk $(55.47 \mathrm{and} 19.80 \mathrm{q} / \mathrm{ha})$ than $0.8 \mathrm{IW} / \mathrm{CPE}$ (I1) and 1.2IW/CPE (I3). Among plant population levels, 83,333 plants per ha $\left(\mathrm{P}_{2}\right)$ gave better baby corn yield with husk and increased yield of baby corn by $2.35 \%$ over the 66,666 plants per ha $\left(\mathrm{P}_{1}\right)$ and proved significantly superior on the other treatments.

\section{Introduction}

Among the cereals, maize (Zea mays L.) ranks third in total world production after wheat and rice and it is staple food in many countries, particularly in the tropics and subtropics (FAO, 2012). Maize is considered as the "Queen of cereals". Being aC4 plant, it is capable of utilizing solar radiation more efficiently even at higher radiation intensity. In Indian agriculture, maize assumes a special significance on account of its utilization as food, feed and fodder besides several industrial uses. It is cultivated in several states. In India, it is grown on $9.43 \mathrm{mha}$ with the production and productivity of $24.35 \mathrm{mt}$ and $2583 \mathrm{~kg} / \mathrm{ha}$, respectively (Government of India,
2014). Rajasthan ranks first in respect of area, where in this crop occupied 926.7ha area with production of 1502.2 tonnes and productivity of $1621 \mathrm{~kg} / \mathrm{ha}$ (Government of Rajasthan, 2014). Out of total production, 45 per cent is consumed as a staple food in various forms viz., bread, biscuits, cookies or transformed into cornflakes, soups, fresh-roasted sweets, boiled cobs and vegetables etc. Specialty corn viz. sweet corn, popcorn, baby corn, high oil corn etc. assume tremendous market potential not only in India but in international market as well. These specialty corns with their high market value are perfectly suitable to periurban agriculture. For diversification and 
value addition of maize as well as the growth of the food processing industry, growing maize for vegetable purpose, which is known as 'baby corn'. Baby corn is not a separate type of corn like sweet corn or popcorn but it may be any hybrid/ variety that can be used as baby corn. Baby corn is dehusked maize ear, harvested young especially when the silk has either not emerged or just emerged and no fertilization has taken place or we can say the shank with un pollinated silk is baby corn. Baby corn ear is light yellow colour with regular row arrangement, $10-12 \mathrm{~cm}$ long and a diameter of $1.0-1.5 \mathrm{~cm}$, are preferred in the market. The economic product is harvested just after silk emergence (1-2cm long). Baby corn is an important crop of Thailand, Taiwan and in India; recently baby corn has gained popularity as valuable vegetable in Delhi, Uttar Pradesh, Haryana, Maharashtra, Karnataka, Andhra Pradesh and Meghalaya. Baby corn is used as an ingredient in chop suey (China dish), soup, deep fried baby corn with meat, rice and other vegetables. It is highly nutritive (Paroda, 1994). Its nutritive value per $100 \mathrm{~g}$ of edible portion is 89.10 percent moisture, $8.20 \mathrm{~g}$ carbohydrates, $1.90 \mathrm{~g}$ protein, $28.0 \mathrm{mg}$ calcium, $86.0 \mathrm{mg}$ phosphorus, $0.10 \mathrm{mg}$ iron, $0.50 \mathrm{mg}$ thiamine, $0.08 \mathrm{mg}$ riboflavin, $11.0 \mathrm{mg}$ ascorbic acid and total sugar 1.66 percent (Muthukumar et al., 2005). It is consumed both raw and cooked. Cooking does not change its culinary and physical properties significantly. It's by products such as tassel, young husk, silk and green stalks provide good cattle feed, which are also very nutritious.

In order to achieve higher yield, maintenance of spacing is the most important factor. Spatial arrangements of plant govern the shape and size of the leaf area per plant, which in turn influence efficient interception of radiant energy and proliferation and growth of root and their activity. The cobsper plant decreased significantly with reduction in plant spacing.
Cob weight with and without husk decreased with increase in plant population due to closer spacing (Aravinth et al., 2011). Increase in plant population resulted in higher barrenness. Maximum yield can be expected only when plant population allows individual plant to achieve their maximum inherent potential. Thus, there is need to work out an optimum plant spacing by adjusting inter and intra row spacing in relation to other agronomic factors. In summer season (March to May), the water requirement of the crop increases with increase in temperature, so precision water management may not only improve water use efficiency but also helps in better plant growth and development by maintaining optimum soil moisture regime throughout the crop growing period with reduced environmental impact (Javaid and Khalid, 2009). Moisture stress leads poor plant sand and leaf area index resulting poor grain and fodder maize yield (Shafiq et al., 2003). While excess moisture causes poor plant stand as well as stunted plant growth.

Among different approaches of scheduling irrigation, use of cumulative pan evaporation (CPE) and water sensitive critical crop growth stages are simple and feasible (Shinde et al., 2009). Therefore, the present investigation was undertaken to study the effect to irrigation management and plant population on the performance of summer baby corn under different plant population.

\section{Materials and Methods}

A field experiment was carried out summer season of 2015 at the Instructional Farm, Rajasthan College of Agriculture, MPUAT, Udaipur, Rajasthan. The geographical location of the site is situated at South-Eastern part of Rajasthan at an altitude of 582.5 meter above means a level with $24^{\circ} 35^{\prime}$ N latitude and $73^{\circ} 42^{\prime} \mathrm{E}$ longitude. The region falls under agro- climatic zone IVA "Sub-humid Southern 
Plain and Aravalli Hills of Rajasthan". The region has typical sub-tropical climatic conditions characterized by mild winters and moderate summers associated with high relative humidity during the months of July to September. The mean annual rainfall of the region is $637 \mathrm{~mm}$, most of which is contributed by south-western monsoon from June to September. The soil of experimental field was clay loam in texture and slightly alkaline in reaction and calcareous in nature. The experiment was laid out in split plot design with three replications on well prepared and leveled field. There were 18 treatment combinations which comprised of three irrigation level (main plot treatment) and six plant population levels (subplot treatment). The main plots received three irrigation level, $0.8 \mathrm{IW} / \mathrm{CPE} \quad$ (I1), $\quad 1.0 \mathrm{IW} / \mathrm{CPE}(\mathrm{I} 2)$ and1.2IW/CPE(I3) with six plant population levels viz. 66,666 plants per ha(P1), 83,333 plants per ha( $\mathrm{P} 2), 88,888$ plants per ha( $\mathrm{P} 3), 1$, 11,111 plants per ha(P4), 1,33,333plants per ha (P5) and 1,66,666 plants perha ( $\left.\mathrm{P}_{6}\right)$. In sub plots, all the treatments were randomly allocated to different plots in each replication in a plot size of $5.4 \mathrm{mx} 4 \mathrm{~m}$.A uniform dose of $125 \mathrm{~kg} \mathrm{~N}$ per ha and $40 \mathrm{~kg} \mathrm{P}_{2} 05$ per ha was applied as basal to all the plots through urea, diammonium phosphate respectively. Sowing was done uniformly in all the plots manually by using $25-35 \mathrm{~kg}$ seeds $/ \mathrm{ha}$ at a rows pacing of as per treatment. Before sowing, the seeds were treated with thirum @ $3 \mathrm{~g} / \mathrm{kg}$ of seeds. Extra plants were thinned out after 20 days of planting to maintain optimum plant population.

All the standard agronomic management practices were adopted. Statistical analysis of data was performed with SAS version 9.3. Data were analyzed with the help of analysis of variance (ANOVA) to determine the significant effect of different treatments and significance of the difference between means of the treatments performed based on $p$ value (the actual probability at which the effect was significant). The grouping was done at 5\% level of significance, and the treatments having the same letters are non-significant at the given level of significance.

\section{Results and Discussion}

\section{Effect on growth attributes}

The plant height on 20DAS was not influenced significantly due to irrigation level (IW/CPE) and plant population. But application of 1.0 (IW/CPE) irrigation level recorded higher plant height at 40 DAS and at harvest and plant population of 1, 66,666 plants per ha gave significantly higher plant height at 40 DAS and at harvest. It is well established fact that moisture stress in crops has reported to cause a decrease in translocation of carbohydrates and growth substances, disturb nitrogen metabolism, forced loss of turgor and consequently cause of reduction in sink size and its growth (Versan and Phillips, 1978). In dry matter, plant population of 83,333 plants per ha gave significantly higher dry matter accumulation (7.27g/plant) at 20DAS over other plant population treatments but it was found at par with 66,666 plants per ha $(7.05 \mathrm{~g} /$ plant $)$ and at 40DAS 1.0 (IW/CPE) irrigation level recorded higher dry matter $(75.31 \mathrm{~g} / \mathrm{plant})$ at 40 DAS. The reduction in a fore said physiological and biochemical activities seems to have led to lower photosynthetic rate per unit area, ultimately lower accumulation of biomass per plant. Leaf area index recorded maximum at 20 and 40 DAS by Plant population at 83,333 plants per ha. In irrigation level 1.0 (IW/CPE) irrigation level recorded higher LAI at 40 DAS. Irrigation and plant population levels significantly influenced CGR and RGR at 2040 and 40-60DAS. Highest CGR and RGR recorded with 1.0 (IW/CPE) irrigation level at 20-40 and 40-60 DAS. 
Int.J.Curr.Microbiol.App.Sci (2017) 6(7): 2274-2282

Table.1 Effect of irrigation management and plant population on the plant height and dry matter accumulation of baby corn

\begin{tabular}{l} 
Treatments \\
\hline Irrigation(IW/CPE) \\
0.8 \\
1.0 \\
1.2 \\
$\mathrm{SEm} \pm$ \\
$\mathrm{CD}(\mathrm{P}=0.05)$ \\
Plant population(Plants ha $\left.{ }^{-1}\right)$ \\
66,666 \\
83,333 \\
88,888 \\
$1,11,111$ \\
$1,33,333$ \\
$1,66,666$ \\
$\mathrm{SEm} \pm$ \\
$\mathrm{CD}(\mathrm{P}=0.05)$ \\
\hline
\end{tabular}

\begin{tabular}{|c|c|c|c|c|c|}
\hline \multicolumn{3}{|c|}{ Plant height (cm) } & \multicolumn{3}{|c|}{ Dry matter accumulation (g plant ${ }^{-1}$ ) } \\
\hline 20 DAS & 40 DAS & At harvest & 20 DAS & 40 DAS & $\underset{\text { harvest }}{\text { At }}$ \\
\hline 31.96 & 119.81 & 159.45 & 6.83 & 66.56 & 156.62 \\
\hline 33.65 & 132.05 & 178.88 & 6.91 & 75.31 & 176.68 \\
\hline 34.06 & 128.87 & 177.38 & 6.82 & 73.62 & 170.76 \\
\hline 0.98 & 3.24 & 4.80 & 0.18 & 2.04 & 4.77 \\
\hline NS & 9.00 & 13.37 & NS & 5.67 & 13.25 \\
\hline 32.39 & 116.46 & 162.01 & 7.05 & 77.65 & 187.49 \\
\hline 33.18 & 126.59 & 170.95 & 7.27 & 73.97 & 180.43 \\
\hline 33.40 & 127.57 & 172.95 & 6.81 & 72.66 & 170.18 \\
\hline 33.42 & 128.44 & 173.46 & 6.77 & 69.38 & 162.58 \\
\hline 33.42 & 130.26 & 175.14 & 6.69 & 69.24 & 155.40 \\
\hline 33.54 & 132.15 & 176.90 & 6.55 & 68.08 & 152.06 \\
\hline 0.84 & 3.21 & 3.03 & 0.10 & 1.13 & 2.27 \\
\hline NS & 9.26 & 8.76 & 0.30 & 3.27 & 6.56 \\
\hline
\end{tabular}


Int.J.Curr.Microbiol.App.Sci (2017) 6(7): 2274-2282

Table.2 Effect of irrigation management and plant population on the LAI and RGR

\section{Treatments}

\section{Irrigation(IW/CPE)}

0.8

1.0

1.2

$\mathrm{SEm} \pm$

$\mathrm{CD}(\mathrm{P}=0.05)$

Plant population(Plants ha' $\left.{ }^{-1}\right)$

66,666

83,333

88,888

$1,11,111$

$1,33,333$

1, 66,666

$\mathrm{SEm} \pm$

$\mathrm{CD}(\mathrm{P}=0.05)$
Leaf area index

20 DAS

40 DAS

0.69

0.65

0.64

0.01

0.03

0.67

0.70

0.57

0.65

0.63

0.55

0.01

0.02

\begin{tabular}{l}
40 DAS \\
\hline 2.85 \\
3.11 \\
3.08 \\
0.06 \\
0.16
\end{tabular}

3.26

3.46

2.88

2.99

2.58

2.90

0.04

0.11
RGR ( g g $^{-1}$ day $\left.^{-1}\right)$

20-40 DAS 40-60 DAS

\begin{tabular}{cc}
0.671 & 0.1137 \\
\hline 0.672 & 0.1194 \\
0.671 & 0.1190 \\
0.001 & 0.0011 \\
NS & 0.0032
\end{tabular}

$\begin{array}{ll}0.6732 & 0.1200 \\ 0.6748 & 0.1158 \\ 0.6715 & 0.1183 \\ 0.6712 & 0.1163 \\ 0.6707 & 0.1168 \\ 0.6696 & 0.1170 \\ 0.0008 & 0.0009 \\ 0.0020 & 0.0020\end{array}$


Int.J.Curr.Microbiol.App.Sci (2017) 6(7): 2274-2282

Table.3 Effect of irrigation management and plant population on the CGR and NAR

\begin{tabular}{|c|c|c|c|c|}
\hline \multirow{2}{*}{ Treatments } & \multicolumn{2}{|c|}{ CGR $\left(\mathrm{gm}^{-2} \mathrm{day}^{-1}\right)$} & \multicolumn{2}{|c|}{ NAR $\left(\mathrm{gm}^{-2}\right.$ leaf area day $\left.{ }^{-1}\right)$} \\
\hline & 20-40 DAS & 40-60 DAS & 20-40 DAS & 40-60 DAS \\
\hline \multicolumn{5}{|c|}{ Irrigation(IW/CPE) } \\
\hline 0.8 & 31.87 & 47.83 & 26.49 & 96.41 \\
\hline 1.0 & 36.63 & 53.28 & 32.78 & 116.16 \\
\hline 1.2 & 35.67 & 50.66 & 31.39 & 111.94 \\
\hline $\mathrm{SEm} \pm$ & 0.83 & 1.37 & 1.16 & 4.36 \\
\hline $\mathrm{CD}(\mathrm{P}=0.05)$ & 2.30 & 3.80 & 3.22 & 12.11 \\
\hline \multicolumn{5}{|c|}{ Plant population(Plants ha $\left.{ }^{-1}\right)$} \\
\hline 66,666 & 23.55 & 36.63 & 34.92 & 130.20 \\
\hline 83,333 & 27.78 & 44.34 & 33.86 & 131.81 \\
\hline 88,888 & 29.27 & 43.35 & 29.28 & 105.25 \\
\hline $1,11,111$ & 34.78 & 51.77 & 29.66 & 103.83 \\
\hline $1,33,333$ & 41.69 & 57.42 & 26.46 & 86.73 \\
\hline $1,66,666$ & 51.28 & 70.00 & 27.13 & 91.20 \\
\hline $\mathrm{SEm} \pm$ & 0.55 & 1.15 & 0.67 & 2.36 \\
\hline $\mathrm{CD}(\mathrm{P}=0.05)$ & 1.60 & 3.33 & 1.93 & 6.81 \\
\hline
\end{tabular}


Table.4 Effect of irrigation management and plant population on the yield attributes

\begin{tabular}{|c|c|c|c|c|}
\hline \multirow{2}{*}{ Treatment } & \multicolumn{4}{|c|}{ Yield attributes } \\
\hline & Baby corn length $(\mathrm{cm})$ & Width of baby corn (cm) & No. of baby corn plant ${ }^{-1}$ & Weight of baby corn(g) \\
\hline \multicolumn{5}{|c|}{ Irrigation(IW/CPE) } \\
\hline 1.0 & 7.60 & 1.39 & 1.21 & 19.88 \\
\hline 1.2 & 7.40 & 1.35 & 1.20 & 18.16 \\
\hline $\mathrm{CD}(\mathrm{P}=0.05)$ & 0.35 & 0.07 & NS & 1.47 \\
\hline \multicolumn{5}{|c|}{ Plant population(Plants ha ${ }^{-1}$ ) } \\
\hline 66,666 & 7.89 & 1.41 & 1.24 & 19.83 \\
\hline 83,333 & 8.26 & 1.45 & 1.26 & 21.38 \\
\hline 88,888 & 7.14 & 1.33 & 1.22 & 17.85 \\
\hline $1,66,666$ & 6.60 & 1.25 & 1.13 & 16.58 \\
\hline $\mathrm{SEm} \pm$ & 0.10 & 0.02 & 0.02 & 0.29 \\
\hline $\mathrm{CD}(\mathrm{P}=0.05)$ & 0.30 & 0.05 & 0.07 & 0.84 \\
\hline
\end{tabular}


Table.5 Effect of irrigation management and plant population on the yields

\begin{tabular}{|c|c|c|c|c|}
\hline \multirow[b]{2}{*}{ Treatments fodder yield } & \multicolumn{3}{|c|}{ Yields $\left(q h^{-1}\right)$} & \multirow[t]{2}{*}{$\begin{array}{l}\text { Biological yield } \\
\qquad\left(\mathbf{q ~ h a} \mathbf{h}^{-1}\right)\end{array}$} \\
\hline & $\begin{array}{l}\text { Green with husk } \\
\end{array}$ & \multicolumn{2}{|c|}{$\begin{array}{c}\text { Baby corn yield Baby corn yield } \\
\text { without husk }\end{array}$} & \\
\hline \multicolumn{5}{|l|}{ Irrigation(IW/CPE) } \\
\hline 0.8 & 259.91 & 46.63 & 18.62 & 278.53 \\
\hline 1.0 & 285.82 & 55.47 & 19.80 & 305.62 \\
\hline 1.2 & 266.91 & 51.22 & 17.50 & 284.41 \\
\hline $\mathrm{SEm} \pm$ & 6.87 & 1.72 & 0.59 & 7.42 \\
\hline $\mathrm{CD}(\mathrm{P}=0.05)$ & 19.09 & 4.77 & 1.63 & 20.61 \\
\hline \multicolumn{5}{|l|}{$\begin{array}{l}\text { Plant population } \\
\text { (Plants ha }\end{array}$} \\
\hline 66,666 & 282.50 & 54.88 & 20.33 & 302.83 \\
\hline 83,333 & 291.91 & 56.17 & 21.72 & 313.63 \\
\hline 88,888 & 268.47 & 49.56 & 18.34 & 286.81 \\
\hline $1,11,111$ & 271.32 & 52.12 & 18.73 & 290.06 \\
\hline $1,33,333$ & 254.78 & 47.29 & 17.01 & 271.79 \\
\hline $1,66,666$ & 256.30 & 46.64 & 15.72 & 272.02 \\
\hline $\mathrm{SEm} \pm$ & 4.26 & 1.08 & 0.38 & 4.52 \\
\hline $\mathrm{CD}(\mathrm{P}=0.05)$ & 12.29 & 3.12 & 1.09 & 13.06 \\
\hline
\end{tabular}


In plant population level 1,66,666 plants per ha recorded highest CGR at 20-40 and 40-60 DAS and RGR is recorded with 66,666 plants per ha at 40-60 DAS. NAR is recorded highest with 1.0 (IW/CPE) irrigation level (Tables 1-3).

\section{Effect on yield attributes and yield}

All yield attributes were significantly affected by the irrigation level and plant population level except no. of baby corn /plant. Irrigation level significantly influenced the baby corn length, width of baby corn and weight of baby corn. 1.0 (IW/CPE) irrigation level recorded significantly greater length of corn $(7.60 \mathrm{~cm})$, baby corn width $(1.39 \mathrm{~cm})$ and weight of baby corn $(19.88 \mathrm{~g})$ but all irrigation level did not show significant difference in respect to no. of babycorn/plant. Among the plant population levels 88,888 plants per ha recorded higher corn length $(8.26 \mathrm{~cm})$, corn width $(1.45 \mathrm{~cm})$, number of baby corn plant $(1.26 \mathrm{~cm})$ and weight of baby corn $(21.38 \mathrm{~g})$. Maximum green fodder yield was $(285.82 \mathrm{q} / \mathrm{ha})$, baby corn yield with husk $(55.47 \mathrm{q} / \mathrm{ha})$ baby corn yield without husk (19.80q/ha) and biological yield (305.62q/ha). Recorded by 1.2(IW/CPE) irrigation level. Among the plant population level 83,333 plants per ha recorded higher green fodder yield (291.91qha), baby corn yield with husk $(56.17 \mathrm{q} / \mathrm{ha})$, baby corn yield without husk $(21.72 \mathrm{q} / \mathrm{ha})$ and biological yield (313.63q/ha) (Tables 4 and 5).

In conclusion, based on the findings of the present investigation, it may be concluded that the irrigation at 1.0IW/CPE proved superior with respect to various growth parameters viz. plant height, dry matter accumulation, LAI, CGR and RGR which attributed to the higher green fodder and baby corn yield. It proved to be more suitable irrigation level forgetting higher yield. Among the plant population level 83,333 plants per ha found superior over the other levels.

\section{References}

Aravinth, V., Kuppuswamy, G. and Ganapathy, M. 2011. Growth and yield of baby corn (Zea mays L.) as influenced by intercropping, planting geometry and nutrient management. Indian J. Agri. Sci., 81(9): 875-77.

FAOSTAT. 2012. Crop production data-maize 2005. http://faostat.org.retrievedon17April 2010.

Government of India. 2014. Directorate of economics and statistics, Department of Agriculture and cooperation, Ministry of Agriculture, Government of India.

Government of Rajasthan. 2014. Vital Agriculture Statistics, Statistics cell, Directorate of Agriculture, Pant krishi Bhawan, Jaipur Pp. 47.

Javaid, A.T. and Khalid, U. 2009. Regulated deficit irrigation scheduling of maize crop. Sarhad J. Agri., 25(3): 441-450.

Muthukumar, V.B., Velayudham, K. and Thavaprakaash, N. 2005. Growth and yield of baby corn (Zea mays L.) as influenced by plant growth regulators and different time of nitrogen application. Res. J. Agr. and Bio. Sci., 1(4): 303-307.

Paroda, R.S. 1994. Thailand mein baby cornkisafaltakikahani. Kheti, 48: 21.

Shafiq, M., Hassan, I. and Hussain, Z. 2003. Maize crop production and water use efficiency as affected by planting methods. Asian J. Plant Sci., 2(1): 141-144.

Shinde, S.A., Shelk, D.K. and Sawargaonkar, G.L. 2009. Effect of irrigation schedules and integrated nutrient management on yield and nutrient uptake by rabi maize. (Zea mays L.) Int. J. Plant Sci., 4(1): 2426.

Versan, V. and Ronald Phillips, E. 1978. Effect of soil water stress on growth and nutrient accumulation in corn. Agron. J., 613-618.

\section{How to cite this article:}

Meena, R.K., R.C. Tiwari, V.D. Meena, J.L. Charpota and Meena, A.K. 2017. Effect of Irrigation Management and Plant Population on the Performance of Summer Babycorn (Zea mays L.). Int.J.Curr.Microbiol.App.Sci. 6(7): 2274-2282.

doi: https://doi.org/10.20546/ijcmas.2017.607.267 